\title{
Lymphocyte subpopulations in rheumatoid synovial tissue
}

\author{
A. WANGEL AND M. KLOCKARS \\ From the Fourth Department of Medicine, University of Helsinki, and \\ Rheumatism Foundation Hospital, Heinola, Finland
}

SUMMARY Synovial tissue obtained at synovectomy of the knee joint in 21 patients with rheumateid arthritis contained a significantly lower proportion of $\mathrm{T}$ lymphocytes as measured by spontanequs rosette formation with nonsensitized sheep red blood cells than did synovial fluid or blood from the same patients. There was no concomitant increase in synovial tissue lymphocytes with B-cell markers such as surface immunoglobulin or Fc fragment receptors. Removal of lymphocyte receptors whh trypsin followed by culture to allow new receptors to form, led to an increase in rosette forming ce就, suggesting that part of the synovial cells without B- or T-cell markers may be T lymphocytes wh blocked receptors.

Interest in immunological mechanisms in the pathogenesis of rheumatoid arthritis has largely concerned serological markers such as rheumatoid factor (Franklin et al., 1957) and immune complexes (Rodman et al., 1967; Baumal and Broder, 1968; Kinsella et al., 1969). More recent evidence has suggested cell mediated immunity to synovial antigens (Bacon et al., 1973) and there have been studies of lymphocyte subpopulations in the blood (Papamichail et al., 1971; Mellbye et al., 1972; Williams et al., 1973; Keith and Currey, 1973; Yu et al., 1974; Clements et al., 1974; Micheli and Bron, 1974; Vernon-Roberts et al., 1974) and synovial fluid of rheumatoid patients (Mellbye et al., 1972; Froland et al., 1973; Winchester et al., 1973; VernonRoberts et al., 1974). However, there are few published reports on the proportion of $T$ and $B$ lymphocytes in rheumatoid synovium (Abrahamsen et al., 1975; van Boxel and Paget, 1975; Loewi et al., 1975). We describe the results of such a study which differs from the previous ones in that $T$ and $B$ markers were sought immediately the lymphocytes had been harvested from the synovial tissue by mechanical mincing and gradient centrifugation. In 3 patients the proportion of synovial T-cells was again determined after the lymphocytes had been subjected to trypsinization and 30-hour culture.

Accepted for publication July 8, 1976

Correspondence to Prof. A. Wangel, Department of Medicine, Queen Elizabeth Hospital, Woodville, South Australia 5024

\section{Patients}

The 21 patients with rheumatoid arthritis whese blood and synovial tissue lymphocytes were stude्ed were under treatment at the Rheumatism Foundation Hospital, Heinola, Finland. 4 were receiving prëdnisolone at the time but in none did the daily dese exceed $10 \mathrm{mg}$. Clinical details are given in Table $\exists$. Blood lymphocytes only were studied in a furthep. 6 patients, none of whom were receiving corticosteraid drugs. The control group consisted of healtify laboratory staff and patients attending the casuafiy clinic with minor complaints (mean age $\pm S D$, $37 \cdot 2 \pm 11 \cdot 8$ years).

Table 1 Clinical details of 21 patients with rheumatoid arthritis

\begin{tabular}{|c|c|c|c|}
\hline \multicolumn{4}{|l|}{ Sex } \\
\hline Male & 6 & & ภ \\
\hline Female & 15 & & \\
\hline Age (years) & & & n \\
\hline $\begin{array}{l}\text { Mean } \\
\text { Range }\end{array}$ & $\begin{array}{l}43 \cdot 5 \\
13-59\end{array}$ & & \\
\hline Mean duration of RA & 15 years & & c \\
\hline Rheumatoid factor & & & \\
\hline $\begin{array}{l}\text { Present } \\
\text { Absent }\end{array}$ & $\begin{array}{r}16 \\
5\end{array}$ & & $\stackrel{0}{\frac{C}{C}}$ \\
\hline Gold treatment within preceding 6 months & & 5 & \\
\hline Intra-articular steroids & & 2 & \\
\hline Intra-articular osmium & & $\mathbf{0}$ & 7 \\
\hline
\end{tabular}

Synovial tissue, synovial fluid, and blood we obtained at synovectomy of the knee joint. Tissge 
specimens were minced with scissors and incubated with periodic shaking for 2 hours at room temperature in Dulbecco phosphate buffered saline (PBS), containing $500 \mathrm{IU}$ heparin and one drop of a latex suspension (Bacto-Latex 0.81 u, Difco) in each $10 \mathrm{ml}$. Blood and synovial fluid samples were collected into heparin tubes and incubated as above before dilution with two volumes of PBS before lymphocyte separation.

\section{LYMPHOCYTE SEPARATION}

Ficoll-Hypaque gradient centrifugation according to the method of Boyum (1968) was used for lymphocyte separation.

\section{ROSETTE FORMING CELLS}

Lymphocytes were tested for their ability to form rosettes with sheep red blood cells (SRBC) as described by Jondal et al. (1972), except that the initial incubation of lymphocytes with SRBC was done at $+4^{\circ} \mathrm{C}$, that fetal calf serum was used in a final concentration of $40 \%$ to stabilize the rosettes, and that one drop of $0.5 \%$ toluidine blue in PBS was added to the tubes immediately before resuspension and counting.

\section{SURFACE IG BEARING CELLS}

These cells were detected by staining with FITC conjugated antihuman gammaglobulin (Behringwerke, Germany). Incubation for 30 minutes at $+4^{\circ} \mathrm{C}$ was followed by three washes in PBS. The percentage of labelled cells was counted in a Leitz Dialux Incident Light UV microscope. Cells containing two or more latex beads were regarded as phagocytic and excluded from the calculations.

\section{FC RECEPTOR BEARING CELLS}

These cells were determined by the method of Dickler and Kunkel (1972). Human gammaglobulin (16.5\% human normal immunoglobulin, Kabi, Stockholm) was diluted to a concentration of $50 \mathrm{mg} / \mathrm{ml}$, incubated at $56^{\circ} \mathrm{C}$ for 30 minutes, and heat aggregated at $66^{\circ} \mathrm{C}$ for 15 minutes. It was then centrifuged to obtain a pellet which was homogenized in PBS at $\mathrm{pH} 8.0$. After centrifugation at $3000 \mathrm{~g}$ for 30 minutes the protein concentration of the supernatant was adjusted to $2 \mathrm{mg} / \mathrm{ml}$. One drop of this solution and one drop of PBS containing $2 \%$ bovine serum albumin (BSA, Armour) and $0.02 \% \mathrm{Na}$ azide were added to one drop of the lymphocytes to be tested. After incubation for 30 minutes at $+4^{\circ} \mathrm{C}$ the cells were washed three times in the BSA-azide buffer and then incubated for 30 minutes at $4{ }^{\circ} \mathrm{C}$ with one drop of FITC conjugated antihuman IgG (Behringwerke, Germany). After three further washes in BSA-azide buffer the percentage of fluoresceinlabelled cells was determined as above.
WHITE CELL COUNTS

Total leucocyte and differential white cell counts were made from blood taken at operation into EDTA.

\section{Results}

Patients with rheumatoid arthritis had a leucocytosis compared with control subjects, but absolute lymphocyte counts were not significantly different in the two groups (Table 2). The percentages and absolute numbers in the peripheral blood of rosette forming cells, surface Ig bearing cells, and Fc receptor bearing cells were also similar in the two groups (Table 3 ).

Rheumatoid synovial tissue contained a significantly lower proportion of rosette forming cells than either synovial fluid or blood (Table 4). There was no significant difference between serologically positive and serologically negative patients, nor between patients who had received gold therapy within the past 6 months and those who had not (Table 5).

The low proportion of synovial tissue rosette forming cells was not accompanied by an increase in the percentage of cells bearing B-cell markers and thus more than half of the lymphocytes harvested from rheumatoid synovial tissue appeared to carry neither $\mathbf{T}$ nor $\mathbf{B}$ lymphocyte markers. Further experiments were carried out to try to determine whether some of these cells might be $T$ lymphocytes which were incapable of forming rosettes because the receptors for SRBC were blocked.

Table 2 Total blood leucocytes and lymphocytes $($ mean $\pm S D)$

\begin{tabular}{llll}
\hline & $n$ & $\begin{array}{l}\text { Leucocytes } / \mathrm{mm}^{3} \\
\left(\times 10^{9} / l\right)\end{array}$ & $\begin{array}{l}\text { Lymphocytes } / \mathrm{mm}^{3} \\
\left(\times 10^{9} / l\right)\end{array}$ \\
\hline Control group & 24 & $\begin{array}{l}6216 \pm 2035 \\
(6.2 \pm 2 \cdot 0)\end{array}$ & $\begin{array}{l}2020 \pm 881 \\
(2.0 \pm 0.9)\end{array}$ \\
RA & 27 & $\begin{array}{l}7692 \pm 2055 \\
(7 \cdot 7 \pm 2.0)\end{array}$ & $\begin{array}{l}1596 \pm 679 \\
(1.6 \pm 0.7)\end{array}$ \\
\hline
\end{tabular}

Statistical comparison by Students ' $\mathrm{t}$ ' test.

Table 3 Percentages and absolute numbers of rosette forming (RFC), surface Ig bearing (SIg), and Fc receptor bearing $(F C)$ lymphocytes in peripheral blood from patients with $R A$ and control subjects (mean $\pm S D$ )

\begin{tabular}{cllll}
\hline & $n$ & $R F C$ & SIg cells & Fc cells \\
\hline Control & 24 & $66 \pm 8 \cdot 0 \%$ & $19 \pm 5 \%$ & $21 \pm 7 \%$ \\
group & $1309 \pm 538 / \mathrm{mm}^{3}$ & $380 \pm 180 / \mathrm{mm}^{3}$ & $401 \pm 182 / \mathrm{mm}^{3}$ \\
& NS & NS & NS \\
RA & 27 & $64 \pm 12 \%$ & $26 \pm 13 \%$ & $25 \pm 10 \%$ \\
& $1039 \pm 486 / \mathrm{mm}^{3}$ & $428 \pm 288 / \mathrm{mm}^{3}$ & $424 \pm 243 / \mathrm{mm}^{3}$ \\
\hline
\end{tabular}


Table 4 Percentages of lymphocytes with T-and B-cell markers in blood, synovial fluid, and synovial tissue from patients with $R A($ mean $\pm S D)$

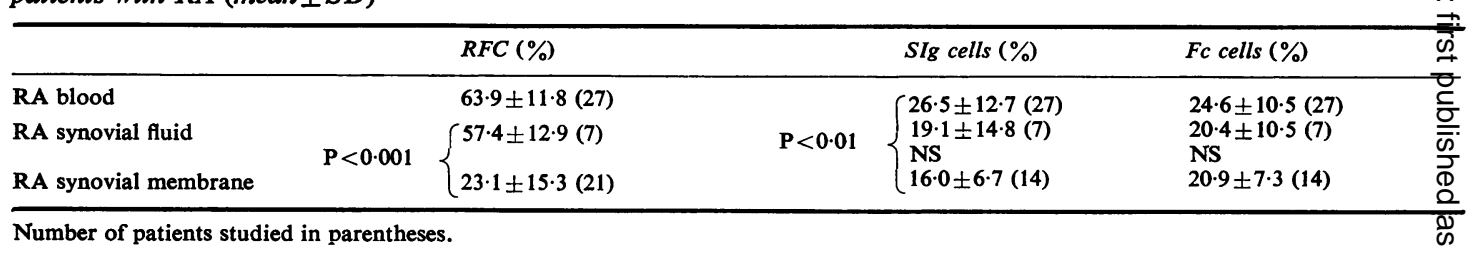

Table 5 Comparison of synovial tissue RFC in RA patients with regard to serological status and recent gold treatment (mean $\pm S D)$

\begin{tabular}{lrll}
\hline & $n$ & $\begin{array}{l}\text { Synovial tissue } \\
R F C(\%)\end{array}$ & Student's 't' test \\
\hline Seropositive & 16 & $20 \cdot 7 \pm 15 \cdot 0$ & \\
Seronegative & 5 & $32 \cdot 2 \pm 13 \cdot 5$ & $\mathrm{t}=1 \cdot 53, \mathrm{NS}$ \\
Recent gold treatment & 5 & $31 \cdot 8 \pm 20 \cdot 4$ & \\
No gold last 6 months & 16 & $19 \cdot 8 \pm 12 \cdot 6$ & $\mathrm{t}=1 \cdot 58, \mathrm{NS}$ \\
\hline
\end{tabular}

SRBC ROSETTE FORMATION BY TRYPSIN TREATED LYMPHOCYTES

Lymphocytes were isolated from peripheral blood and synovial tissue of patients with rheumatoid arthritis as described above and SRBC rosettes were prepared from an aliquot (native cells). The remainder of the lymphocytes were incubated for 30 minutes at room temperature with a $0.15 \%$ solution of trypsin (Worthington Biochemicals, 2 x crystallized) in $\mathrm{Ca}$ - and $\mathrm{Mg}$-free PBS. The cells were washed three times in Dulbecco's PBS and an aliquot was tested for SRBC rosette formation (trypsin treated cells). The remainder of the cells were incubated in BHK-21 medium supplemented with $10 \%$ fetal calf serum, glutamine, penicillin, and streptomycin for 30 hours at $37^{\circ} \mathrm{C}$ and, after the culture medium had been washed away, tested for rosette forming activity (trypsin treated and cultured cells).

In the 3 patients studied trypsin treatment virtually eliminated the rosette forming ability of synovial

Table 6 Effect of trypsin treatment and culture on rosette forming ability of synovial tissue and peripheral blood lymphocytes from $R A$ patients

\begin{tabular}{llll}
\hline $\begin{array}{l}\text { Source of } \\
\text { lymphocytes }\end{array}$ & $\begin{array}{l}\text { Native } \\
\text { cells }\end{array}$ & $\begin{array}{l}\text { \%RFC trypsin } \\
\text { treated cells }\end{array}$ & $\begin{array}{l}\text { Trypsin treated } \\
\text { and cultured cells }\end{array}$ \\
\hline $\begin{array}{llll}\text { Synovial tissue } \\
\text { Case } 1\end{array}$ & 36 & 0 & 72 \\
2 & 64 & 6 & 86 \\
3 & 48 & 9 & 90 \\
$\begin{array}{ccc}\text { Peripheral blood } \\
4\end{array}$ & 55 & 5 & 52 \\
5 & 79 & 0 & 44 \\
\hline
\end{tabular}

tissue lymphocytes (Table 6). However, trypsinizg cells which had been cultured for 30 hours ha्d regained this ability so that the proportion capabfe of rosette formation was now higher than that of native cells and of a similar order to that seen peripheral blood and synovial fluid. In the 2 patients studied the proportion of rosette forming cells in peripheral blood lymphocytes was not increased above initial values by trypsin treatment and culture.

\section{Discussion}

The main finding of this study was the unexpected fy low proportion of rosette forming cells in rheumtoid synovial tissue. The relative proportion $\bar{g} f$ lymphocytes bearing T- or B-cell markers in normol synovial tissue is not known; hence it cannot be stated with certainty that the low proportion $\overrightarrow{\mathrm{g} f}$ T-cells in rheumatoid synovium is abnormal. It however, significantly lower than the proportion rheumatoid synovial fluid.

The most obvious explanation for this finding is that T-cell damage or depletion could occur during harvesting of lymphocytes from synovial tissue, particularly during mincing. However, lymphocytes derived from other synovial tissue specimens treated in an identical manner were more than $95 \%$ viabge by Trypan blue exclusion.

Another possibility is that T-cells might be 'fetter in the synovial tissues through attachment to ce bound antigens and therefore not readily released by mincing. If this were the case B-cells might have bean expected to be proportionally increased. Howevœl, this was not so, instead the low proportion of T-cefts was accompanied by an increase in cells with neither T nor B markers.

Thirdly, it is possible that some of the synovial tissue cells without $\mathbf{T}$ or B markers are T-cells which are unable to form rosettes for immunological gr other reasons. Incubation of normal peripheral blood lymphocytes with rheumatoid synovial flugh blocks the C3 receptor (a B-cell marker) whife incubation with normal synovial fluid has a similar though less marked effect (Mellbye et al., 1972). It\&s 
conceivable that some of the cells harvested from rheumatoid synovial tissue were T-cells whose SRBC receptors were made unavailable through attachment of a synovial tissue antigen or antigens to adjacent receptors or in some other but less specific way. T-cell specific antilymphocyte antibodies (Terasaki et al., 1970; Mittal et al., 1970; Lies et al., 1973) should be detected by staining for SIg and are thus unlikely to be the reason.

SRBC receptors can be removed from the cell surface by treatment with trypsin but regenerate when the cells are washed and cultured (Jondal et al., 1972). In our study the synovial tissue lymphocytes of only 3 patients were treated in this manner but the increase in $\mathrm{T}$ lymphocytes suggested that most of the cells which initially had neither $T$ nor $B$ characteristics were in fact $\mathrm{T}$ lymphocytes. This accords with the recent report of Loewi et al. (1975) who found that, after trypsin treatment and 4-day culture, up to $94 \%$ of rheumatoid synovial membrane lymphocytes formed SRBC rosettes. Two other studies (Abrahamsen et al., 1975; van Boxel and Paget, 1975) also reported that the majority of lymphocytes studied after enzyme treatment and culture formed SRBC rosettes. There is thus good agreement between these studies and ours that most of the lymphocytes were harvested from the rheumatoid synovial membrane by mechanical means with or without enzyme digestion form SRBC rosettes when tested some hours later. In addition, our study shows that most of these cells are unable to manifest this T-cell marker at the time of their release from the synovial tissue. If this phenomenon were due to blocking by synovial antigen(s), later to be released into the culture medium, attempts at isolation of such antigen(s) might be of interest.

We thank Professor K. Vainio and his team of surgeons at Heinola for their generous assistance, Professor O. Wegelius for helpful discussions, and Miss Tuula Vesterinen for technical assistance. This work was supported by a grant from the Sigrid Juselius Foundation.

\section{References}

Abrahamsen, T. G., Natvig, J. B., Froland, S. S., and Pahle, J. (1975). Separation and immunological characterisation of lymphocytes in synovial tissue from patients with rheumatoid arthritis. (Abst.) Scandinavian Journal of Rheumatology, 4, Suppl. 8.

Bacon, P. A., Cracchiolo, A., Bluestone, R., and Goldberg, L. S. (1973). Cell-mediated immunity to synovial antigens in rheumatoid arthritis. Lancet, 2, 699-702.

Baumal, R., and Broder, I. (1968). Studies into the occurrence of soluble antigen-antibody complexes in disease. Clinical and Experimental Immunology, 3, 555-569.
Boyum, A. (1968). Isolation of mononuclear cells and granulocytes from human blood. Isolation of mononuclear cells by one centrifugation and of granulocytes by combining centrifugation and sedimentation at $1 \mathrm{~g}$. Scandinavian Journal of Clinical and Laboratory Investigation, 21, Suppl. 97, 177-189.

Clements, P. J., Yu, D. T. Y., Levy, J., Paulus, H. E., and Barnett, E. V. (1974). Effects of cyclophosphamide on B and $\mathrm{T}$ lymphocytes in rheumatoid arthritis. Arthritis and Rheumatism, 17, 347-353.

Dickler, H. B., and Kunkel, H. G. (1972). Interaction of aggregated $\gamma$-globulin with B lymphocytes. Journal of Experimental Medicine, 136, 191-196.

Franklin, E. C., Holman, H. R., Muller-Eberhard, H. J., and Kunkel, H. G. (1957). An unusual protein component of high molecular weight in the serum of certain patients with rheumatoid arthritis. Journal of Experimental Medicine, 105, 425-438.

Froland, S. S., Natvig, J. B., and Husby, G. (1973). Immunological characterization of lymphocytes in synovial fluid from patients with rheumatoid arthritis. Scandinavian Journal of Immunology, 2, 67-74.

Jondal, M., Holm, G., and Wigzell, H. (1972). Surface markers of human T and B lymphocytes. A large population of lymphocytes forming nonimmune rosettes with sheep red blood cells. Journal of Experimental Medicine, 136, 207215.

Keith, H. I., and Currey, H. L. F. (1973). Rosette formation by peripheral blood lymphocytes in rheumatoid arthritis. Annals of the Rheumatic Diseases, 32, 202-207.

Kinsella, T. D., Baum, J., and Ziff, M. (1969). Immunofluorescent demonstration of an IgG- $\beta 1 \mathrm{c}$ complex in synovial lining cells of rheumatoid synovial membrane. Clinical and Experimental Immunology, 4, 265-271.

Lies, R. B., Messner, R. P., and Williams, R. C. (1973). Relative T-cell specificity of lymphocytotoxins from patients with systemic lupus erythematosus. Arthritis and Rheumatism, 16, 369-375.

Loewi, G., Lance, E. M., and Reynolds, J. (1975). Study of lymphoid cells from inflamed synovial membranes. Annals of the Rheumatic Diseases, 34, 524-528.

Mellbye, O., Messner, R. P., Debord, J. R., and Williams, R. C. (1972). Immunoglobulin and receptors for C3 on lymphocytes from patients with rheumatoid arthritis. Arthritis and Rheumatism, 15, 371-379.

Micheli, A., and Bron, J. (1974). Studies on T and B lymphocytes in rheumatoid arthritis. Annals of the Rheumatic Diseases, 33, 435-436.

Mittal, K. K., Rossen, R. D., Sharp, J. T., Lidsky, M. D., and Butler, W. T. (1970). Lymphocyte cytotoxic antibodies in systemic lupus erythematosus. Nature, 225, 1255-1256.

Papamichail, M., Brown, J. C., and Holborow, E. J. (1971). Immunoglobulins on the surface of human lymphocytes. Lancet, 2, 850-852.

Rodman, W. S., Williams, R. C., Bilka, P. J., and MullerEberhard, H. J. (1967). Immunofluorescent localization of the third and fourth component of complement in synovial tissue from patients with rheumatoid arthritis. Journal of Laboratory and Clinical Medicine, 69, 141-150.

Terasaki, P. I., Mottironi, V. D., and Barnett, E. V. (1970). Cytotoxins in disease: autocytotoxins in lupus. New England Journal of Medicine, 283, 724-728.

van Boxel, J., and Paget, S. (1975). Predominantly T-cell infiltrate in rheumatoid synovial membranes. New England Journal of Medicine, 293, 517-520.

Vernon-Roberts, B., Currey, H. L. F., and Perrin, J. (1974). $T$ and $B$ cells in the blood and synovial fluid of rheumatoid patients. Annals of the Rheumatic Diseases, 33, 430-434. 
Williams, R. C., Deboard, J. R., Mellbye, O. J., Messner, R. P., and Lindstrom, F. D. (1973). Studies of T and B lymphocytes in patients with connective tissue diseases. Journal of Clinical Investigation, 52, 283-295.

Winchester, R. J., Siegal, F. P., Bentwich, Z. H., and Kunkel, H. G. (1973). Alterations in the proportions of $B$ and $T$ lymphocytes in rheumatoid arthritis joint fluids with low complement and increased complexes. (Abst.) Arthriti. and Rheumatism, 16, 138.

Yu, D. T., Clements, P. J., Peter, J. B., Levy, J., Paulus, H. and Barnett, E. V. (1974). Lymphocyte characteristics 苗 rheumatoid patients and the effect of azathioprine therap. Arthritis and Rheumatism, 17, 37-44. 